\title{
PENINGKATKAN MANAJEMEN PESERTA DIDIK BERBASIS SEKOLAH MELALUI SUPERVISI MANAJERIAL DI SMPN 1 SUNGAI RAYA
}

\author{
Slamet Riyadi \\ Kepala SMP Negeri 1 Sungai Raya \\ Email: slametriyadiptk680102@gmail.com
}

\begin{abstract}
The principal has a great duty and responsibility in encouraging and facilitating the quality of educational program at a school. One of this is carrying out the main managerial duty and supervisory on teachers and education staff. According to the results of managerial supervision that have been carried on from January to April 2018, it was obtained 56\% of all components of students management. To overcome this matter, the researcher has conducted a School Action Research entitled The Principal's Effort In Improving Students Management Of School-Based Through Managerial Supervision of Smp Negeri 1 Sungai Raya. This research was conducted by involving the vice principal of students affairs and administration staff. The target of this research is the achievement of vice principal of students affairs and administration staff in the students management of school-based. The students management of school-based is a regulation for students that is began when they registered as the student until they have graduated at the school. This research was conducted through two cycles, in the first cycle $75 \%$ was obtained with good qualifications and 4 incomplete components of $25 \%$ with medium qualifications. In the second one, all components of the management of students have completed (100\%). Based on these results, the principal has more motivation to improve the achievement of other school employees in order that completion of school administrative duties run better.
\end{abstract}

\section{Keywords: Principal, Student Management, Managerial Supervision}

\section{PENDAHULUAN}

Salah satu bentuk desentralisasi pendidikan dalam era otonomi daerah adalah pelaksanaan manajemen peningkatan mutu pendidikan berbasis sekolah. Manajemen berbasis sekolah ini menekankan pentingnya kepemimpinan kepala sekolah yang efektif, pemberdayaan sekolah dalam mengelola sumber daya pendidikan secara mandiri dan kreatif, pengambilan keputusan partisipatif untuk meningkatkan mutu dan kinerja sekolah.

Kepala sekolah memiliki fungsi dan tanggung jawab yang besar dalam mendorong dan memfasilitasi proses pendidikan yang bermutu di sekolah yang dipimpinnya. Berdasarkan Peraturan Menteri Pendidikan dan Kebudayaan Nomor 6 Tahun 2018 Pasal 15 tentang tugas pokok kepala sekolah pada ayat 1 yaitu beban kerja kepala sekolah sepenuhnya untuk melaksanakan tugas pokok manajerial, pengembangan kewirausahaan, dan supervisi kepada guru dan tenaga kependidikan. Mengingat materi tugas kepala sekolah sangat luas, sehingga sulit untuk dilaksanakan saat ini. Hal ini disebabkan adanya keterbatasan waktu, biaya, dan kemampuan peneliti, maka pada penelitian ini hanya memilih tugas kepala sekolah pada manajerial khususnya manajemen peserta didik berbasis sekolah melalui supervisi manajerial.

Manajerial adalah fungsi supervisi yang berkenaan dengan aspek pengelolaan sekolah yang terkait langsung dengan peningkatan efisiensi dan efektivitas sekolah yang mencakup perencanaan, koordinasi, pelaksanaan, penilaian, serta pengembangan kompetensi SDM kependidikan dan sumberdaya lainnya. Kompetensi utama seorang supervisor terletak pada kemampuan personalnya. Persyaratan untuk semua supervisor, yaitu: teknikal, human, manajerial atau administrative. Ketiga kompetensi tersebut disebut gabungan keterampiilan (skill mix). Dimensi teknikal berkaitan dengan kemampuan menggunakan pengetahaun, metode, tekhnik, dan peralatan dalam melaksanakan kurikulum dan sistem pengalamannya. Keterampilan manajerial mencangkup perencanaan, organisasi, staffing, pendelegasian tanggung jawab, manajemen. Keterampilan manajerial supervisor juga mencangkup kemampuan menghubungkan kerja unit dengan unit yang lain bagian dari lembaga pendidikan. Kerja unit ini bisa berupa hasil kerja 
guru satu dengan lainnya atau kerja dari staf administrasi sebagai pendukungnya.

Keterampilan human dalam supervisi merupakan kemampuan mempengaruhi orang lain agar mau melakukan perubahan untuk perbaikan atau peningkatan. Untuk itu seorang supervisor harus mampu berkomunikasi dengan baik, termasuk kemampuan menyampaikan saran dengan baik, yaitu mudah dipahami. Jadi seorang supervisor harus menguasai pengetahuan tentang substansi yang dipantau dan dievaluasi, memiliki keterampilan berhubungan dengan orang lain termasuk berkomunikasi, dan memiliki keterampilan dalam pengelolannya.

Kompetensi-kompetensi yang harus dimiliki oleh supervisor dapat juga disebut sebagai berikut: (1) Mampu melakukan supervisi sesuai prosedur dan teknik-teknik yang tepat; (2) Mampu melakukan monitoring, evaluasi dan pelaporan program pendidikan sesuai dengan prosedur yang tepat; (3) Memahami dan menghayati arti, tujuan dan teknik supervisi; (4) Menyusun program supervisi pendidikan; (5) Melaksanakan program supervisi pendidikan; (6) Memanfaatkan hasil-hasil supervisi; dan (7) Melaksanakan umpan balik dari hasil supervisi.

Esensi supervisi manajerial adalah pemantauan dan pembinaan terhadap pengelolaan dan administrasi sekolah. Dengan demikian fokus supervisi ini ditujukan pada pelaksanaan bidang garapan manajemen sekolah, yang antara lain meliputi: (a) manajemen kurikulum dan pembelajaran, (b) kesiswaan, (c) sarana dan prasarana, (d) ketenagaan, (e) keuangan, (f) hubungan sekolah dengan masyarakat, dan (g) layanan khusus.Sasaran.

Menurut Sutisna (1993) mengartikan kepala sekolah sebagai seseorang yang mengatur dan mengendalikan jalannya organisasi dan administrasi sekolah, sehingga tujuan sekolah dapat dicapai secara lebih efektif dan efisien. Kepala sekolah memiliki fungsi dan tanggung jawab yang besar dalam mendorong dan memfasilitasi proses pendidikan yang bermutu di sekolah yang dipimpinnya. Berdasarkan Peraturan Menteri Pendidikan dan Kebudayaan Nomor 6 Tahun 2018 Pasal 15 tentang tugas pokok kepala sekolah pada ayat 1 yaitu beban kerja kepala sekolah sepenuhnya untuk melaksanakan tugas pokok manajerial, pengembangan kewirausahaan, dan sepervisi kepada guru dan tenaga kependidikan.
The Liang Gie (1978) mengatakan manajemen sebagai segenap perbuatan mengerakkan sekelompok orang atau mengarahkan segala fasilitas dalam suatu usaha kerja sama untuk mencapai tujuan tertentu. Maka dapat disimpulkan bahwa manajemen ialah suatu kegiatan yang dilakukan secara bersama-sama oleh dua orang atau lebih yang didasarkan atas aturan tertentu untuk mencapai suatu tujuan.

Menurut Knezevich (1961), menajemen peserta didik atau pupil personnel administration adalah suatu layanan yang memusatkan perhatian pada pengaturan, pengawasan dan layanan siswa di kelas dan diluar kelas seperti: pengenalan, pendaftaran, layanan individu seperti pengembangan keseluruhan kemampuan, minat, kebutuhan sampai ia matang disekolah. Manajemen peserta didik berbasis sekolah adalah manajemen peserta didik yang memberikan tekanan pada empat pilar manajemen berbasis sekolah, yakni: mutu, kemandirian, partisipasi masyarakat dan transparasi.

Menurut Aedi (2016:114), tugas pokok urusan administrasi peserta didik sebagaimana yang disebutkan dalam artikel yang berjudul "Tugas dan Fungsi Tenaga Administrasi Sekolah" (MaS Al-Muthmainnah, 2012), yaitu "bertanggung jawab kepada tata usaha dan melaksanakan administrasi peserta didik". Adapun tugasnya sebagai berikut: (1). Membuat daftar Nomor Induk Peserta Didik. (2). Membuat buku klaper peserta didik. (3). Mengisi buku induk peserta didik (4). Mengisi buku mutasi peserta didik. (5). Membuat daftar keadaan peserta didik. (6). Membukukan daftar keadaan peserta didik. (7). Membukukan daftar peserta didik perkelas. (8). Mencatat pendaftaran peserta didik baru. (9). Membuat usulan peserta ujian. (10). Menyimpan daftar lulusan. (11). Menyimpan daftar penerimaan atau penyerahan STTB. (12). Membuat buku leger . (13). Menyediakan blanko pemanggilan orang tua peserta didik. (14). Membuat surat keterangan dan surat mutasi peserta didik. (15). Mengisi papan data keadaan peserta didik.

Pada penelitian ini bidang garapan yang diteliti adalah bidang kesiswaan. Sehubungan dengan itu, perlu SMP Negeri 1 Sungai Raya membutuhan suatu manajemen di bidang peserta didik. Manajemen peserta didik atau sering disebut manajemen kesiswaan merupakan salah satu bidang operasional dalam pengelolaan sekolah. Manajemen pesarta didik dapat 
diartikan sebagai usaha pengaturan terhadap peserta didik: mulai dari peserta didik tersebut masuk sekolah sampai dengan mereka lulus. Yang diatur secara langsung adalah segi-segi yang berkenaan dengan peserta didik secara tidak langsung. Pengaturan terhadap segi-segi lain selain peserta didik dimaksudkan untuk memberikan layanan yang sebaik mungkin kepada peserta didik.

Sementara itu, Manajemen peserta didik berbasis sekolah adalah Manajemen Peserta didik yang memberikan tekanan pada empat pilar manajemen berbasis sekolah, yakni: mutu, kemandirian, partisipasi masyarakat dan transparasi. Jadi, seluruh aktivitas manajemen peserta didik, haruslah diaksentuasikan pada penonjolan empat pilar manajemen berbasis sekolah tersebut.

Manajemen peserta didik berbasis sekolah adalah suatu pengaturan terhadap peserta didik di sekolah, sejak peserta didik masuk sampai dengan peserta didik lulus. Ruang lingkup manajemen peserta didik berbasis sekolah sebenarnya meliputi aktivitas-aktivitas peserta didik sejak yang bersangkutan lulus, baik berkenaan dengan peserta didik secara langsung, maupun secara tidak langsung (tenaga kependidikan, sumber-sumber pendidikan, saran dan prasarananya).

Berdasarkan uraian diatas, peneliti ingin melakukan penelitian tindakan sekolah dengan judul "Upaya Kepala Sekolah Dalam Meningkatkan Manajemen Peserta Didik Berbasis Sekolah Melalui Supervisi Manajerial di SMP Negeri 1 Sungai Raya".

\section{METODE PENELITIAN}

Tujuan Penelitian Tindakan Sekolah ini, diharapkan terjadi perbaikan dan peningkatan manajemen peserta didik di SMP Negeri 1 Sungai Raya yaitu: (1). Bagi kepala sekolah, menjadi rujukan dan motivasi untuk meningkatkan kreativitas dalam manajemen administrasi peserta didik, terjadinya efektifitas koordinasi antara wakasek kesiswaan, staf tata usaha dengan kepala sekolah dalam tugas seharihari. (2). Bagi wakasek kesiswaan dan staf tata usaha, akan termotivasi dalam melaksanakan tugas yang berhubungan dengan kelengkapan administrasi peserta didik. (3). Bagi sekolah, tersedianya dokumen kelengkapan administrasi peserta didik yang baik, sebagai akibat dari kerjasama dari seluruh warga sekolah sehingga dapat meningkatkan mutu pendidikan.
Adapun kualifikasi administrasi peserta didik yang diharapkan dapat dibedakan atas tiga katagori sebagai berikut: (1) Kualifikasi lengkap dengan katagori baik, yaitu apabila semua dokumen administrasi peserta didik ada, semua komponen-komponen diisi secara baik dan berkesinambungan; (2) Kualifikasi kurang lengkap dengan katagori sedang, yaitu apabila semua dokumen administrasi peserta didik ada, tetapi komponen-komponennya tidak diisi secara lengkap; (3) Kualifikasi tidak ada dengan katagori kurang, yaitu apabila dokumen administrasi peserta didik tidak ada atau tidak dilaksanakan.

Penelitian Tindakan Sekolah dilaksanakan dalam 2 (dua) siklus pada SMP Negeri 1 Sungai Raya, Jl. Adisucipto, km 12,1, Kecamatan Sungai Raya, Kabupaten Kubu Raya mulai tanggal 6 Agustus 2018 sampai dengan tanggal 23 Nopember 2018 dengan langkah-langkah pelaksanaan tindakan pada setiap siklus meliputi:

\section{Siklus pertama}

a. Perencanaan tindakan. Meliputi: (1) Menetapkan materi yang dijadikan penelitian yaitu manajemen peserta didik berbasis sekolah dan supervisi manajerial; (2) Menyusun jadwal pelaksanaan penelitian; (3) Menyusun instrumen yaitu manajemen peserta didik berbasis sekolah dan supervisi manajerial; (4) Menentukan objek atau responden yang mengisi instrumen untuk data awal yaitu wakasek kesiswaan dan staf tata usaha; (5) Menentukan aspek kelengkapan manajemen peserta didik yang perlu perbaikan melalui tahap-tahap tindakan Sekolah melalui observasi dan refleksi.

b. Pelaksanaan tindakan. Meliputi: (1) Wawancara dengan wakasek kesiswaan dan staf tata usaha sebagai responden untuk mengisi instrumen data awal manajemen peserta didik berbasis sekolah dan supervisi manajerial yang sudah dilaksanakan; (2) Menjelaskan cara mengisi instrumen data awal yang telah disiapkan; (3) Responden mengisi dan menjawab instrumen data awal sesuai dokumen manajemen peserta didik berbasis sekolah dan supervisi manajerial yang telah dilaksanakan; (4) Peneliti mengobservasi dengan cara mengamati secara langsung dokumen peserta didik yang ada di sekolah; (5) Peneliti mengisi instrumen observasi sesuai dengan 
dokumen manajemen peserta didik berbasis sekolah dan supervisi manajerial; (6) Menganalisis hasil observasi pelaksanaan Tindakan Siklus I.

c. Refleksi. Berdasarkan analisis hasil pengamatan secara langsung sesuai lembar instrumen data awal dan data lembar instrumen observasi siklus I ternyata dari 16 (enam belas) aspek ruang lingkup manajemen peserta didik di SMP Negeri 1 Sungai Raya, hasilnya adalah sebagai berikut: (1) Ada 12 (dua belas) dokumen peserta didik yang lengkap yaitu dokumen Penerimaan Peserta Didik Baru (PPDB), Struktur Organisasi Peserta didik (OSIS), Program kegiatan ekstrakurikuler, Daftar siswa model 8355, Tata tertib sekolah, Buku Absensi Peserta Didik, Buku Induk Peserta Didik, Buku Leger, Buku Mutasi Peserta Didik, Dokumen prestasi Peserta Didik bidang akademik/non akademik, Dokumen penghargaan peserta Didik berprestasi dan Daftar penerima beasiswa; (2) Ada 4 (empat) dokumen peserta didik yang sudah ada tapi belum lengkap yaitu: Program kegiatan OSIS, Jadwal kegiatan ekstrakurikuler , Dokumen pengiriman Peserta Didik pada berbagai lomba dan Papan statistik Peserta Didik.

\section{Siklus Kedua}

a. Perencanaan Tindakan. Meliputi (1) Mempersiapkan bahan-bahan bimbingan dan pembinaan untuk menyempurnakan kelengkapan administrasi peserta didik sesuai dengan temuan pada siklus I, yaitu Program kegiatan OSIS, Jadwal kegiatan ekstrakurikuler , Dokumen pengiriman Peserta Didik pada berbagai lomba dan Papan statistik Peserta Didik; (2) Mempersiapkan instrumen manajemen peserta didik dan supervisi manajerial; (3) Mempersiapkan bahan refleksi.

b. Pelaksanaan Tindakan. Meliputi (1) Mendiskusikan hasil analisis observasi tindakan Siklus I dengan responden; (2) Mendiskusikan bentuk atau format administrasi peserta didik yang belum ada; (3) Membantu wakasek kesiswaan dan staf tata usaha untuk menyelesaikan dan menyempurnakan administrasi peserta didik; (4) Meminta wakasek kesiswaan dan staf tata usaha untuk mengisi lembar observasi (lembar observasi terlampir); (5) Mengamati kerjasama antara wakasek kesiswaan dan staf tata usaha untuk melengkapi dan membuat format-format administrasi peserta didik; (6) Mengisi lembar instrumen observasi administrasi peserta didik; (7) Menganalisis hasil kedua lembar instrumen observasi untuk refleksi berikutnya.

c. Refleksi. Berdasarkan hasil analisis observasi tindakan siklus II ini, bahwa Penelitian Tindakan Sekolah berhasil dalam meningkatkan upaya pengelolaan administrasi peserta didik dengan indikator keberhasilan sebagai berikut: (1) Tersedia dokumen peserta didik yang lengkap (baik) di SMP Negeri 1 Sungai Raya; (2) Penyimpanan dan pengaturan semua data peserta didik yang baik dan bila diperlukan cepat disiapkan; (3) Ada peningkatan pengelolaan administrasi peserta didik sehingga termotivasi untuk menyelesaikan tugas administrasi sekolah lainnya; (4) Adanya peningkatan kerja sama antara kepala sekolah, wakasek kesiswaan dan staf tata usaha dalam menyelesaikan administrasi peserta didik.

\section{Hasil dan Pembahasan}

Hasil penelitian tindakan sekolah pada siklus 1 dari hasil observasi diperoleh data kelengkapan administrasi peserta didik yaitu dengan katagori baik terdapat pada administrasi (1). Penerimaan peserta didik, (2).Struktur organisasi peserta didik, (3).Daftar siswa model 8355, (4).Tata tertib sekolah, (5).Buku absensi peserta didik, (6).Buku Induk peserta didik, (7).Buku leger, (8).Buku mutasi peserta didik, (9).Daftar penerima beasiswa. Kelengkapan administrasi peserta didik dengan katagori sedang meliputi: (1).Program kegiatan OSIS,(2). Program kegiatan ekstrakurikuler, (3).Jadwal kegiatan ekstrakurikuler, (4).Dokumen pengiriman peserta didik pada berbagai lomba, (5).Dokumen prestasi peserta didik bidang akademik/ non akademik, (6).Dokumen penghargaan peserta didik yang berprestasi, (7).Papan statistik peserta didik. Sedangkan data hasil observasi untuk mengukur kinerja wakasek kesiswaan dan staf tata usaha yaitu dengan katagori baik terdapat pada: (1).Kesungguhan mengikuti bimbingan dalam membuat formatformat yang diperlukan, (2). Adanya diskusi yang aktif antara wakasek kesiswaan dan staf 
tata usaha. Kinerja wakasek kesiswaan dan staf tata usaha dengan katagori sedang terdapat pada: (1). Kesungguhan untuk menyelesaikan kelengkapan administrasi peserta didik di SMP Negeri Sungai Raya, (2).Ada kerjasama antara wakasek kesiswaan dan staf tata usaha dalam penyelesaian administrasi peserta didik, (3). Motivasi terpacu kinerjanya untuk menyelesaikan administrasi peserta didik, (4). Merasakan manfaat dari kelengkapan administrasi peserta didik.

Hasil penelitian tindakan sekolah pada siklus 2 dari hasil observasi diperoleh data kelengkapan administrasi peserta didik yaitu dengan katagori baik dan lengkap terdapat pada administrasi yang meliputi: (1). Penerimaan peserta didik, (2).Struktur organisasi peserta didik, (3).Program kegiatan ekstrakurikuler, (4).Daftar siswa model 8355, (5).Tata tertib sekolah, (6).Buku absensi peserta didik, (7).Buku Induk peserta didik, (8).Buku leger, (9).Buku mutasi peserta didik, (10).Daftar penerima beasiswa, (11).Dokumen prestasi peserta didik bidang akademik /non akademik, (12).Dokumen penghargaan peserta didik berprestasi, (13).Daftar penerima beasiswa. Sedangkan kelengkapan administrasi peserta didik dengan katagori baik tetapi kurang lengkap meliputi: (1).Program kegiatan OSIS, (2).Dokumen pengiriman peserta didik pada berbagai lomba, (3).Papan statistik peserta didik. Data hasil observasi untuk mengukur kinerja wakasek kesiswaan dan staf tata usaha pada siklus 2 yaitu semuanya dengan katagori baik terdapat pada: (1).Kesungguhan mengikuti bimbingan dalam membuat format-format yang diperlukan, (2). Adanya diskusi yang aktif antara wakasek kesiswaan dan staf tata usaha, (3). Kesungguhan untuk menyelesaikan kelengkapan administrasi peserta didik di SMP Negeri Sungai Raya, (4).Ada kerjasama antara wakasek kesiswaan dan staf tata usaha dalam penyelesaian administrasi peserta didik, (5). Motivasi terpacu kinerjanya untuk menyelesaikan administrasi peserta didik, (6). Merasakan manfaat dari kelengkapan administrasi peserta didik.

Berdasarkan hasil observasi siklus 1 pada kelengkapan administrasi peserta didik didapatkan data sebagai berikut: (1) Penelitian Tindakan sekolah pada siklus I belum mencapai sasaran karena dari 16 kelengkapan administrasi peserta didik baru terdapat 12 komponen yang lengkap dan sudah tercapai $75 \%$ dengan kualifikasi baik dan 4 komponen kurang lengkap sebanyak 25\% dengan kualifikasi sedang; (2) Penelitian Tindakan Sekolah pada siklus II semua komponen administrasi peserta didik sudah lengkap (100\%) artinya berkualifikasi baik, sehigga Penelitian Tindakan Sekolah pada siklus II sudah selesai.

Penilaian kinerja wakasek kesiswaan dan staf tata usaha diperoleh data sebagai berikut: (1) Penelitian Tindakan Sekolah pada siklus II sudah ada 2 aspek kinerja wakasek kesiswaan dan staf tata usaha kategori tinggi mencapai $33,33 \%$ yang berkualifikasi baik dan 4 aspek kinerja wakasek kesiswaan dan staf tata usaha kategori sedang dan baru mencapai 66,67\% yang berkualifikasi sedang; (2) Penelitian Tindakan Sekolah pada siklus II didapatkan hasil semua aspek kinerja wakasek kesiswaan dan staf tata usaha sudah kategori tinggi dan sudah mencapai $100 \%$ dan semuanya berkualifikasi baik.

Berdasarkan uraian di atas tentang kelengkapan administrasi peserta didik dan penilaian kinerja wakasek kesiswaan dan staf tata usaha terdapat peningkatan wakasek kesiswaan dan staf tata usaha dalam pengelolaan administrasi peserta didik di SMP Negeri 1 Sungai Raya. Dengan melihat hasil observasi kelengkapan administasi peserta didik dan penilaian kinerja wakasek kesiswaan dan staf tata usaha pada kegiatan Penelitian Tindakan Sekolah ini maka dianggap berhasil dan selesai.

\section{SIMPULAN DAN SARAN Simpulan}

Dari hasil Penelitian Tindakan Sekolah yang dilaksanakan sebanyak 2 (dua) siklus dapat disimpulkan sebagai berikut: (1) Adanya peningkatan upaya kepala sekolah dalam mengelola, manata dan melaksanakan administrasi peserta didik yang baik; (2) Adanya peningkatan upaya kepala sekolah dalam memberdayakan wakasek peserta didik dan staf tata usaha dalam penyelesaian kelengkapan administrasi peserta didik; (3) Adanya kerjasama yang baik antara kepala sekolah, wakasek kesiswaan dan staf tata usaha dalam penyelesaian administrasi peserta didik; (4) Kepala sekolah menjadi termotivasi untuk meningkatkan kinerja wakasek kesiswaan dan staf tata usaha dalam penyelesaian tugas administrasi sekolah yang lain.

Saran

Adapun saran yang peneliti dapat berikan berdasarkan hasil penelitian yang telah dilakukan ialah: (1) Diharapkan kepala 
sekolah selalu berupaya meningkatkan kinerja wakasek kesiswaan dan staf tata usaha dalam mengelola administrasi peserta didik secara berkesinambungan; (2) Upaya peningkatan kinerja kepala sekolah melalui forum Musyawarah Kerja Kepala Sekolah (MKKS) SMP dan studi banding ke SMP yang lain; (3) Diharapkan adanya kerjasama yang baik antara kepala sekolah, wakasek, guru dan staf tata usaha dalam pengelolaan administrasi peserta didik.

\section{DAFTAR PUSTAKA}

Aedi, Nur. 2016. Manajemen Pendidikan dan Tenaga Kependidikan. Yogyakarta: Gosyen Publishing.

Banun, Sri. 2009. Supervisi Pendidikan Meningkatkan Kualitas Profesionalisme Guru. Bandung: Alfabeta.

Depdikbud. 1999. Panduan Managemen Sekolah. Jakarta:Direktorat Pendidikan Menengah Umum.

Depdikbud. 1994. Petunjuk Pelaksanaan Administrasi Pendidikan di Sekolah.
Jakarta: Direktorat Pendidikan Menengah Umum.

Depdiknas. 2000. Rambu-rambu Penilaian Kinerja Sekolah (SLTP dan SMU). Jakarta: Direktorat Jenderal Pendidikan Dasar dan Menengah.

Depdiknas. 2003. Kinerja Kepala Sekolah KBI ke KTI. Jakarta: Direktorat Tenaga Kependidikan.

Depdiknas. 2003. Pengelolaan Kesiswaan. Jakarta: Direktorat Tenaga Kependidikan.

Fauzan. 2016. Pengantar Sistem Administrasi Pendidikan. Yogyakarta: UII Pers.

Hendarman. 2018. Kepala Sekolah Sebagai Manajer. Bandung: Remaja Rosdakarya.

Herabudin. 2009. Administrasi dan Supervisi Pendidikan. Bandung: Pustaka Setia.

Imron, Ali. 2011. Manajemen Peserta Didik Berbasis Sekolah. Malang: Bumi Aksara.

Sutisna, O. 1993. Administrasi Pendidikan: Dasar Teoritis untuk Praktek Profesional. Bandung:Angkasa 